Contents List available at RAZI Publishing

\title{
Prevalence of Ectoparasitic Fauna and Efficacy of Two Commercial Acaricides against Argus persicus in Layer Poultry \\ Zia ud Din Sindhu ${ }^{* 1}$, Zeeshan Shafiq ${ }^{1}$, Muhammad Usman Naseer ${ }^{1}$, Muhammad Nisar Khan ${ }^{1}$, Muhammad Kashif Saleemi ${ }^{2}$, Bilal Aslam ${ }^{3}$, Rao Zahid Abbas ${ }^{1}$, Muhammad Kasib Khan ${ }^{1}$
}

${ }^{1}$ Department of Parasitology, University of Agriculture, Faisalabad-38040, Pakistan

${ }^{2}$ Department of Pathology, University of Agriculture, Faisalabad-38040, Pakistan

${ }^{3}$ Institute of Pharmacy, Physiology and Pharmacology, University of Agriculture, Faisalabad-38040, Pakistan

Corresponding Author Email Address: ziasandhu@hotmail.com

This is an open access article distributed under the Creative Commons Attribution License, which permits unrestricted use, distribution, and reproduction in any medium, provided the original work is properly cited.

\section{ARTICLE DETAILS \\ Article history: \\ Received 22 January 2017 \\ Accepted 03 February 2017 \\ Available online 05 February 2017 \\ Keywords: \\ Tick, Lice, Poultry, Acaricide, Argus persicus}

\begin{abstract}
Ectoparasites are responsible to transmit many bacterial and viral diseases in laying hens. A number of chemicals are used to manage tick infestation in laying birds. These include carbamates, avermectins, herbal products, pyrethroids and organophosphates and out of them pyrethriods are the most potent than all others. This study was designed to determine the prevalence of ectoparasitic fauna and to check the comparative efficacy of two different combinations of commercial acaricides in layer birds in all Tehsils of District Faisalabad, Punjab, Pakistan. A single species of tick Argas (A.) persicus and a single species of lice Lipeurus (L.) caponis were present in the study area. An overall prevalence of ectoparasites was recorded to be $55 \%$ that includes A. persicus 25\% and L. caponis $35 \%$. Number of ticks were counted after every week for four weeks and there was reduction in the percentage of ticks as 40, 53, 65, 80 and $90 \%$ at days 1, 7, 14, 21 and 28 by using Ecofleece (cypermethrin) while it reduced 52, 64, 72, 90 and $100 \%$ at days $1,7,14,21$ and 28 respectively by using $\mathrm{H}$ killer (cypermethrin+ dichlorvos). Results indicated that $\mathrm{H}$ killer was comparatively more efficient $(\mathrm{p}<0.05)$ than Ecofleece.
\end{abstract}

\section{Introduction}

MPoultry production is getting strength in Pakistan and is augmenting at the rate of $20-25 \%$ per year. Currently, Pakistan is ranked 11 th in the poultry production among all Asian countries. This industry has shown remarkable growth during the last decade or so without the involvement of government. Among poultry, layer birds are efficient source of eggs and meat to fulfill the need of protein source and layer meat shares $28 \%$ of the whole meat production in the state. [1]. Production of eggs among the layer birds is variable and it is dependent on many factors like breed of chicken health status, quality of feed, effective management, age of birds at laying, death rate, duration of eggs production, culling rate and infestation with ectoparasites [2]. A range of ectoparasites can affect egg producing birds which include mice, lice, flies and ticks. These ectoparasites play a vital role in decreased productivity, as they transmit various micro-organisms which cause intense economic losses to this business [3].

Lice species that affect the chicken are Goniocoites gallinae, Menacanthus stramineus, Cuclotogaster heterographus, Menopon gallinae, Goniodes gigas and Lipeurus caponis. Among fowl fleas, Ceratophyllus gallinae is considered to be the commonest species of fowl flea. Mites are present on many parts of the body of the layer birds and majority of them are less than one $\mathrm{mm}$ in length and are microscopic. [4]. Poultry red mite Dermanyssus gallinaeis is an important blood feeding ectoparasite, which infests poultry especially laying hens [5]. Among various ecto parasites of layer birds, A persicus is an argasid tick which causes severe damage by sucking the blood and may lead to heavy mortality. This is the most significant tick of poultry which sucks a massive amount of blood every day causing huge economic losses [6]. The tick, A. persicus can lead to progressive weakness by sucking the blood that ultimately leads to dropped production and tick paralysis in birds [7].

For control of ectoparasites, chemical acaricides are used on large scale. Pyrethroids are the most popular acaricides alone and in combination to deal with ectoparasites [8] and this group has its place to the most frequently used set of acaricides because it is considered to possess high acaricidal strength [9]. Thus, this study was designed to determine the prevalence of ectoparasitic fauna and to check the comparative efficacy of two different combinations of commercial acaricides in layer birds in five Tehsils of District Faisalabad, Punjab, Pakistan.

\section{Experimental Methods}

\subsection{Study area}

Faisalabad stands in the rolling flat plains of northeast Punjab, between longitude $73^{\circ} 74$ East, latitude $30^{\circ} 31.5$ North, with an elevation of $604 \mathrm{ft}$ above sea level. The climate of the District can see extremes with a maximum temperature of $50{ }^{\circ} \mathrm{C}\left(122^{\circ} \mathrm{F}\right)$ in summer and a winter temperature of $-2{ }^{\circ} \mathrm{C}$ $\left(28^{\circ} \mathrm{F}\right)$. The mean maximum and minimum temperature in summer are 39 ${ }^{\circ} \mathrm{C}\left(102^{\circ} \mathrm{F}\right)$ and $27^{\circ} \mathrm{C}\left(81^{\circ} \mathrm{F}\right)$ respectively, while in winter, it peaks at around
$17{ }^{\circ} \mathrm{C}\left(63^{\circ} \mathrm{F}\right)$ and $6{ }^{\circ} \mathrm{C}\left(43^{\circ} \mathrm{F}\right)$ respectively. The average yearly rainfall lies only at about $300 \mathrm{~mm}$ and is highly seasonal with approximately half of the yearly rainfall in the two months July and August.

\subsection{Sampling Units:}

Study includes layer birds raised on floor or cage in commercial farms. These farms were considered as clusters and selection of farms was based on one stage cluster sampling by using the following formula [10].

$$
\mathrm{g}=1.962(\mathrm{nVc}+\mathrm{Pexp}(1-\mathrm{Pexp}) / \mathrm{nd} 2
$$

Where; $\mathrm{n}=$ average number of birds per cluster; Pexp = expected prevalence; $\mathrm{d}=$ desired absolute precision; $\mathrm{vc}=$ between cluster variance.

Twenty five farms were selected according to this formula, with 5 farms from each Tehsil of District Faisalabad that include Tehsil Faisalabad, Tehsil Samundari, Tehsil Jaranwala, Tehsil Tandlianwala and Tehsil Jhumra. About 100 birds were screened out from each farm, with a total of 2500 birds for the determination of prevalence of ectoparasites.

\subsection{Development of Questionnaire}

A questionnaire was prepared for the collection of information regarding various associated risk factors that may influence the prevalence of ectoparasites. Questionnaire was refined through formal and informal testing procedures [10].

\subsection{Collection of Ectoparasites}

Collection of ectoparasites was done by using forceps and intense care was taken so that mouth parts may not be destroyed [11]. These ectoparasites were preserved in glycerin alcohol ( 95 parts alcohol and 5 parts glycerin) and kept in McCartney bottles [12]. All the preserved samples were transported to the Department of Parasitology, University of Agriculture, Faisalabad, for their further analysis. These samples were identified according to their morphological characteristics using entomological keys [4].

\subsection{Preparation of Slide Mounts}

The slide preparation methods used, were refined from the methods of Walker, 1994 [13], for preparation of both temporary and permanent slide mounts. The preparation of temporary mounts involved relatively a few steps: maceration; bleaching if required; acidification; dehydration; de-waxing and rehydration if required and mounting. Preparation of permanent, archival mounts involved maceration; bleaching if required; acidification; staining and differentiation; dehydration; de-waxing; clearing and mounting. The time required in each step varied even between specimens from the same sample, from 5 minutes to several hours.

\subsection{Evaluation of Comparative Efficacy of Acaricides:}

Ecofleece ${ }^{\circledR}$ (cypermethrin 10\%) and H-Killer ${ }^{\circledR}$ (cypermethrin 10\% and dichlorvos $10 \%$ ) were purchased from the local market and were used according to manufacturer's instructions. Sixty commercial laying 
ochickens of native breed (about 40 to 50 weeks of age) naturally infested with A. persicus were maintained separately from other birds on a private poultry farm. These birds were divided into three equal groups $(n=20)$. The first group was sprayed once by Ecofleece ${ }^{\circledR}$ and the second group was sprayed once by H-Killer ${ }^{\circledR}$, while the third group was considered as negative control group. After treatment, these birds were mixed again with all other birds [14]. Birds were examined at night for four weeks for the detection and counting of ticks. The total number of live (attached) ticks (larvae, nymphs and adults) on the left side of each bird were counted and multiplied by two [15]. The percentage reduction of the layer birds, was calculated [6], using the following equation:

Reduction $\%=\{$ (ticks in the control group - ticks after treatment $) /$ ticks in the control group $\mathrm{x} 100$.

\subsection{Statistical analysis}

Data regarding prevalence was analyzed by using chi square test and comparative efficacy of acaricides was subjected to ANOVA [16].

\section{Results and Discussion:}

Physical surveys for the presence of ectoparasitic fauna indicated that the maximum infestation was found in the Tehsil Samundari, while the minimum infestation of ectoparasites was found in the Tehsil Tandlianwala as shown in the table 1. A single species of tick A. persicus and a single species of lice L. caponis were present in the study area. An overall prevalence of ectoparasites was recorded to be $55 \%$ that includes $25 \%$ prevalence of the tick A. persicus and 35\% prevalence of lice L. caponis. However, mites and fleas were not prevalent in any Tehsil of the study area (Table 2). Tehsil wise prevalence of A. persicus was 25, 35, 25, 10 and $5 \%$ in Tehsils Faisalabad, Samundari, Jaranwala, Tandlianwala and Jhumra respectively, indicating that the maximum prevalence of the ticks was found to be in Tehsil Samundari (Table 3). The highest prevalence in Tehsil Samundari could be due to the fact that this Tehsil has maximum number of poultry farms as compared to all other Tehsils. The overall prevalence of ectoparasite infestation was also more in Samundari as compared to other tehsils of District Faisalabad. The results of Tehsil wise prevalence of ectoparasite infestation in layer chicken are similar to that of Khan (2001) [6]. Similarly, area wise prevalence of louse L. caponis was $25,35,25,8$ and $7 \%$ in Faisalabad, Samundari, Jarawala, Tandlianwala and Jhumra respectively (Table 4).

Table 1. Tehsil wise ectoparasitic prevalence in the District Faisalabad

\begin{tabular}{|c|c|c|c|}
\hline Tehsil & No of birds Examined & No of Birds Infested & Percent infestation \\
\hline Faisalabad & 500 & 90 & 18 \\
\hline Sumandari & 500 & 225 & 45 \\
\hline Jaranwala & 500 & 110 & 22 \\
\hline Jhumara & 500 & 45 & 9 \\
\hline Tandlianwala & 500 & 30 & 6 \\
\hline
\end{tabular}

Table 2: Overall prevalence of ectoparasites in the District Faisalabad

\begin{tabular}{|c|c|c|c|}
\hline Ectoparasites & No of Birds Examined & No of birds Infested & Percent Infestation \\
\hline \hline Tick & 2500 & 500 & 20 \\
\hline Lice & 2500 & 875 & 35 \\
\hline Mite & 2500 & 0 & 0 \\
\hline Flea & 2500 & 0 & 0 \\
\hline
\end{tabular}

Table 3. Prevalence of Argus persicus in all Tehsils of District Faisalabad

\begin{tabular}{|c|c|c|c|}
\hline Tehsil & No of birds Examined & No of Birds Infested & Percent infestation \\
\hline Faisalabad & 500 & 125 & 25 \\
\hline Sumandari & 500 & 175 & 35 \\
\hline Jaranwala & 500 & 125 & 25 \\
\hline Jhumara & 500 & 50 & 10 \\
\hline Tandlianwala & 500 & 25 & 5 \\
\hline
\end{tabular}

Table 4. Prevalence of Lipeurus caponis in all Tehsils of District Faisalabad

\begin{tabular}{|c|c|c|c|}
\hline Tehsils & No of birds Examined & No of Birds Infested & Percent infestation \\
\hline Faisalabad & 500 & 125 & 25 \\
\hline Sumandari & 500 & 175 & 35 \\
\hline Jaranwala & 500 & 125 & 25 \\
\hline Jhumara & 500 & 40 & 8 \\
\hline Tandlianwala & 500 & 35 & 7 \\
\hline
\end{tabular}

Number of ticks was counted after every week for four weeks and reduction percentage of ticks by using Ecofleece (Cypermethrin) was 40, $53,65,80$ and $90 \%$ at days $1,7,14,21$ and 28 respectively while the reduction percentage of ticks by using $\mathrm{H}$ killer (Cypermethrin+ diclorvos) was $52,64,72,90$ and $100 \%$ at days 1, 7, 14, 21 and 28 respectively (Fig. 1). The results indicated that $\mathrm{H}$ killer was comparatively more efficient $(p<0.05)$ than Ecolfleece. During the course of present study, prevalence of ectoparasites was recorded to be higher in summer months. Similar trends of seasonal ectoparasitic infestation were reported by many other researchers $[17,18]$. A. persicus is a common tick parasitizing chicken and its prevalence has been reported previously by various workers [17-20]. The low temperature and less frequent litter change frequency was found favorable for the lice infestation in this study which was also determined by Nadeem et al. (2007) [21]. Efficacy of cypermethrin was recorded upto 90 percent on day 28 after the first treatment and upto 100 percent efficacy was recorded by a combination of Cypermethrin and Dichlorvos (H-killer) at day 28 similar to those of Khater et al. (2012) [22].

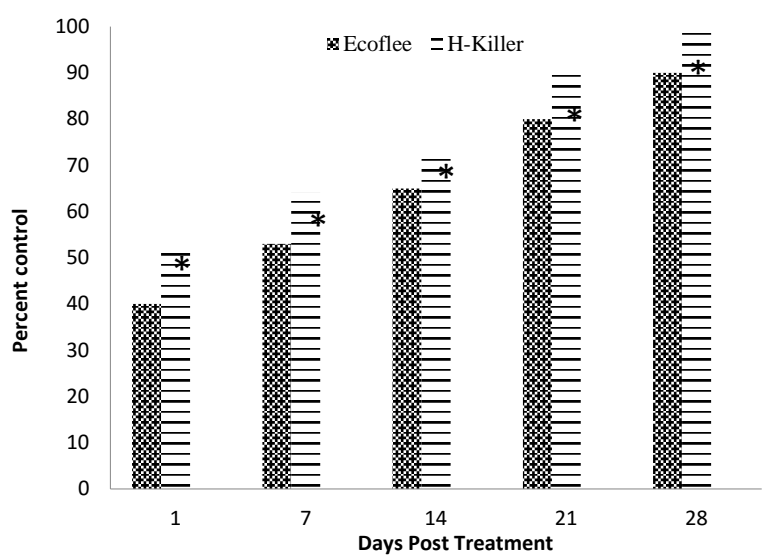

Fig. 1. Comparative efficacy of Ecofleece and H. killer against Argus persicus

\section{Conclusion}

Ectoparasites are responsible for the loss of reproductive performance, create health related issues like weakness and loss of immunity, thus, it becomes difficult for birds to fight against other challenges. Ticks and lice are the most important ectoparasites of poultry as found in this study. Cypermethrin has great potential to control ectoparasites, however, further studies are required to investigate the potential of different combinations of commercial products for their efficacy against ectoparasites of poultry. Furthermore, different surveys are needed to find the prevalence of ectoparasites in poultry so that the exact prevalence can be found and dealt accordingly.

Furthermore, different surveys are needed to find the prevalence of ectoparasites in poultry so that the exact prevalence can be found and dealt accordingly.

\section{References}

[1] GOP. 2015. Economic survey of Pakistan. Govt. of Pakistan. Economic Advisor wing, Finance division, Islamabad.

[2] M. Farooq, M.A. Mian, S. Faisal, F.R. Durrani, M. Arshad, A. Khurshid, Status of broiler breeder stocks in Abbotabad and Mansehra. Sarhad J. Agric. 17 (2001) 489-495.

[3] A. Moller, E. Arriero, E. Lobato, S. Merino, A meta-analysis of parasite virulence in nestling birds, Biol. Rev. Camb. Philos. Soc. 84 (2009) 567-588. 
[4] E.J.L. Soulsby, 1982. Helminths, Arthropods and Protozoa of Domesticated animals. 7th edn, (BailliereTindall, London), 809.

[5] K. Pfister, In: Schnieder, T. (Ed.), Befall mit der RotenVogelmilbe. Veterina. "rmedizinische. Parasitologie. Parey. Verlag. (2006) pp. 634-635.

[6] L.A. Khan, M.N. Khan, Z. Iqbal, A. Qudoos, Comparative acaricidal efficacy of cypermethrin, Ivermectin, trichlorphon and azadirachta indica (neem) In layers naturally infested with Argas persicus. Pak. Agri. Sci. 38 (2001) 3-4.

[7] J.J. Arends, External parasites and, poultry pests. In: Diseases of poultry. 11th edition. Edited by Calnek, W.B., with Barnes, John, H., Beard, W.C., McDougald, L.R. and Saif, Y. M. Iowa State Press, Blackwell Publishing Company, Ames, Iowa. (2003) P 905-930.

[8] C.C. Yang, J.F. Deng. Intermediate syndrome following organophosphate insecticide poisoning, J. Chin. Med. Assoc. 70 (2007) 467-472.

[9] S. Chiappa, S. Padilla, C. Koenigsberger, V. Moser, S. Brimijoin, Slow accumulation of acetylcholinesterase in rat brain during enzyme inhibition by repeated dosing with chlorpyrifos, Biochem. Pharm. 49 (1995) 955-959.

[10] M. Thrushfield, 2007. Veterinary Epidemiology. Blackwell Publishing, Oxford, UK.

[11] E.J.L. Soulsby, Helminths, Arthropods and Protozoa of Domesticated Animals. Bailliere Tindall and Cassel, London, UK. (2006) pp.756-761.

[12] Z. Iqbal, M.S. Sajid, A. Jabbar, R.Z. Abbas, M.N. Khan, Techniques in Parasitology. Higher Education Commission, Islamabad, Pakistan. (2006) pp. 45-49.

[13] A. Walker, The arthropods of human and domestic animals. 1st edition, (1994) Chapman and Hall, London.

[14] H.F. Khater, M.Y. Ramadan, The acaricidal effects of peracetic acid against Boophilus annulatus and Argas persicus, Acta. Sci. Vet. 35 (2007) 29-40.

[15] A.A. Kinsey, L.A. Durden, J. Oliver, Tick infestation of birds in coastal Georgia and Albama, J. Parasitol. 86 (2000) 251-254

[16] M. Thrushfield, Veterinary Epidemiology, 2nd Edition, (1995) Blackwell Publishing, Oxford, UK.

[17] M.S. Phulan, W.M. Bhatti, S.N. Buriro, Incidence of Argas persicus in poultry, Pak. Vet. J. 4 (1984) 174-5.

[18] L.A. Khan, Studies on the prevalence, economic losses and chemotherapy of tick infestation on commercial layers, 2001. M.Sc. Thesis. Faculty of Veterinary Science, University of Agriculture, Faisalabad, Pakistan.

[19] J. Ahmed, Use of pestoban for the control of lice in poultry, Int. J. Indig. Med. 5 (1986) 11-13.

[20] S.M. Habeeb, M.A. Sayed, K.M. El-Kammah, Studies on chicken acquired resistance to Argas (persicargas) persicus (Acari: Argasidae) due to repeated infestation, J. Egypt. 205 (2001) 109-115.

[21] M. Nadeem, M.N. Khan, Z. Iqbal, M.S. Sajid, M. Arshad, M. Yascen, Determinants influencing prevalence of louse infestations on layers of district Faisalabad, Pakistan, Brit. Poult. Sci. 48 (2007) 546-550

[22] H.F. Khater, S.A. Seddiek M.M. El-Shorbagy, A.M. Ali, The acaricidal efficacy of peracetic acid and deltamethrin against the fowl tick, Argas persicus, infesting laying hens, Parasitol. Res. 112 (2012) 259-269. 